\title{
INCREASED MOE AND MOR VALUES OF DENSIFIED BOARDS USING MOE/MOR AND MOR/MOE RATIOS
}

\author{
Iskandar*, Budiarso Edy, Wardhani Isna Yuniar, Budi Agus Sulisyo \\ Politeknik Pertanian Negeri Samarinda, Indonesia \\ *E-mail: iskandar.smd.799@gmail.com
}

\begin{abstract}
Densification is one of the effective techniques for improving the strength of low wood density. This technique is the process of pressing wood so that it increases in volume but decreases in density. This research focused on the densification of Sengon wood species (Paraserianthes falcataria) with a combination of two factors: compaction target (Factor I) and heating time (Factor II). Dunnet's test results showed that an insignificant increase for Modulus of Elasticity (MOE) occurred at the compaction target of $20 \%$, while for MOR (modulus of Rupture) was at the compaction target of $20 \%$ with a heating time of 0 . However, using the comparison method, the MOE values of densified boards calculated by the MOR unit increased, while the MOR values of densified boards calculated by the MOE unit decreased. Thus, a new phenomenon occurred that the actual increase in MOE and MOR values of densified boards was indicated by the increase and decrease in the comparative values.
\end{abstract}

\section{KEY WORDS}

Modulus of elasticity, modulus of rupture, MOE/MOR ratio.

Theoretically, wood is plastic and elastic, so it is easy to shape. With simple technology, wood density can be increased by densification. Wood with increased density will be more rigid and stiffer so that it can be used for specific applications, for example, as the material for floors, ceilings, and others.

Until now, the demand for wood in the market remains high because the community's need for wood is irreplaceable, either as a building material, furniture or others. In fulfilling the market demand for timber, producers are currently providing the market with various types of mixed wood because some commercial varieties of wood such as Meranti (Shorea sp.), Kapur (Dryobalanops), and others are highly difficult to obtain. The use of mild steel and aluminum as the construction material has been replaced by wood since both are limited in terms of availability (metals are non-renewable resources) and the price (metals are pretty expensive, especially for the common people).

Murhofik (2000) and Rilatupa (2000) in Wardhani (2005) have suggested that densification of Sengon and Aghatis woods up to $50 \%$ results in increased density of more than 100\%, increased MOE and MOR values of $90 \%$ (Murhofik, 2000) and improved mechanical properties of $100-246 \%$ (Rilatupa 2000).

Densification on Pulai (Alstonia scholaris) wood species could increase the wood density up to $30 \%$ with a decrease in the thickness from $6.5 \%$ to $2.9 \%-4.5 \%$, indicating that densification affects the dimensional stability of wood (Farah, 2009).

This research used Sengon wood species, representing the type of wood from Hutan Tanaman Industri $(H T I)^{1}$. Sengon grows faster and spreads widely in areas owned by companies or those by the community. Sengon has a low specific gravity of 0.33 , so its density needs to increase (Martawijaya and Kartasujana, 1977).

Densification can also increase wood strength properties, such as flexural strength (MOE, MOR, and stress at the proportion limit), compressive strength, tensile strength, shearing strength, stiffness, and crushing strength more than $150 \%$ (USDA, 1999).

\footnotetext{
${ }^{1}$ Industrial Plantation Forest.
} 
The benefit of this research is to provide information on the increased MOE and MOR values after the densification process.

\section{METHODS OF RESEARCH}

The MOE and MOR values were calculated using the Universal Testing Machine (UTM) tool, while the effect of the treatments and the interaction of the two combined factors (compaction target and heating time) was analyzed using a completely randomized design of 2 (two) factors with $3 \times 3$ designs. Furthermore, the flexural values were calculated using the MOE/MOR ratio and changes in the stiffness values were calculated using the MOR/MOE ratio.

Preparation of Wood Samples. The Sengon tree (Paraserianthes falcataria) used in this research was about $80 \mathrm{~cm}$ in diameter. Samples were taken in a straight section in the middle of the stem. These samples were then made into boards with a thickness of $4 \mathrm{~cm}$ and a length of $2 \mathrm{~m}$. Following the required samples, the wood used was between the radial and tangential planes about $10 \mathrm{~cm}$ from the pith and $10 \mathrm{~cm}$ from the edge of the stem. These boards were left and placed in the open air for about 3 months, to be then made into 1 (one) sample piece (control) sized $40 \mathrm{~cm} \times 40 \mathrm{~cm} \times 2.5 \mathrm{~cm}, 1$ (one) sample piece sized $40 \mathrm{~cm} \times 40$ $\mathrm{cm} \times 3.0 \mathrm{~cm}$, and 1 (one) sample piece sized $40 \mathrm{~cm} \times 40 \mathrm{~cm} \times 3.5 \mathrm{~cm}$. Before the densification process, the boards were air-dried until they reached $12-18 \%$ moisture content for approximately 6 (six) weeks.

The Process of Densification. Before densification, the sample boards were boiled for 45 minutes at $100^{\circ} \mathrm{C}$. The boards were added after water boiled. After the boiling was done, the boards were immediately wrapped in aluminum foil and put into a pressing machine. Pressing was done after the temperature reached $150^{\circ} \mathrm{C}$. There were 2 (two) factors combined, namely compaction target and heating time. The measures of compaction target were $2.5 \mathrm{~cm}$ (at $20 \%$ target), $3.0 \mathrm{~cm}$ (at $33 \%$ target), and $3.5 \mathrm{~cm}$ (at $43 \%$ target), while the measures of the heating time were 0 minutes ( $\left.0^{\prime}\right), 3$ minutes ( $\left.3^{\prime}\right)$ and 6 minutes (6'). Pressing was carried out so that when the compaction target thickness and heating time were reached, the pressing machine would automatically turn off, and the samples were taken out after 24 hours. After the densification process, the densified boards were air-dried again for about 6 (six) weeks until the moisture content reached 12-18\%.

The Process of Making Test Samples. The mechanical properties tested were Modulus of Elasticity (MOE) and Modulus of Rupture (MOR). The testing of mechanical properties in this research referred to the JIS Z 2113 (1963). The illustration of the shape and size of the tested samples can be seen in the following figure.

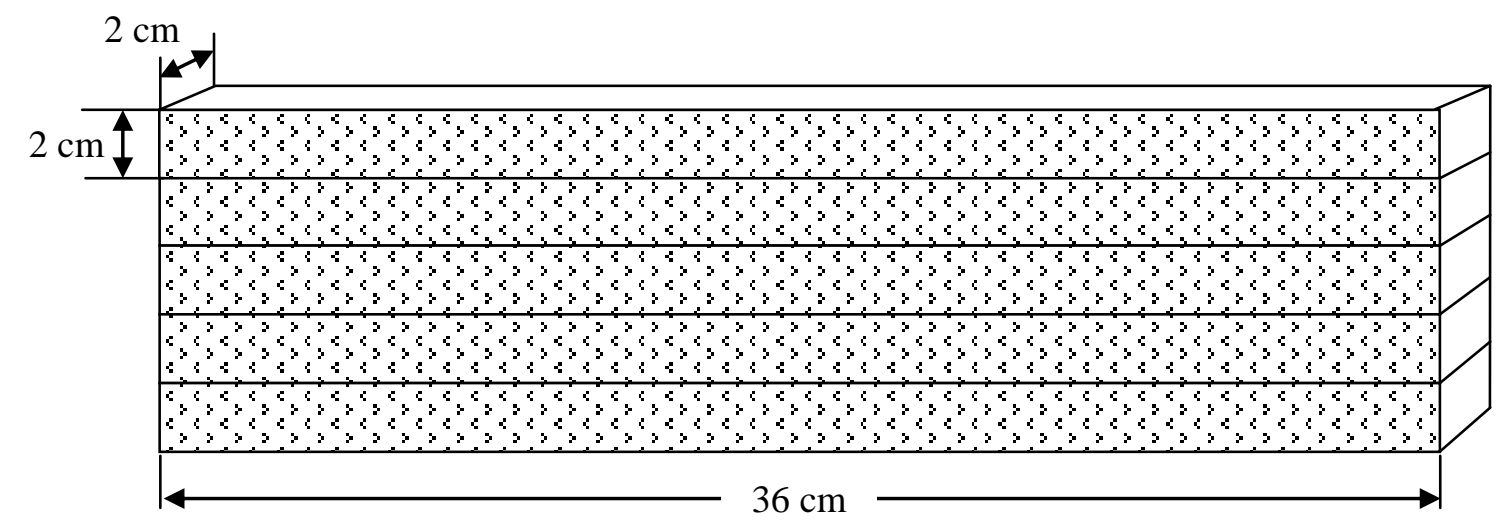

Figure 1 - Samples for MOE and MOR Tests

This research used a Completely Randomized Design with a two-factorial experiment, consisting of Factor I (compaction target of $20 \%, 33 \%$, and $43 \%$ ) and Factor II (Heating Time of 0', 3', and 6'), with 5 (five) replications respectively. 


\section{RESULTS AND DISCUSSION}

The MOE value variance analysis showed that the densification process was influenced by the compaction target treatments, heating time, and the interaction of the two. However, based on Dunnet's advanced test results, the $20 \%$ compaction target did not show a significant difference.

Table 1 - Increased MOE Values Based on Dunnet's Test Results

\begin{tabular}{|l|l|l|l|l|l|}
\hline Target \& Time & $\mu 1(\mathrm{MOE})$ & $\mu 2($ Control) & $|\mu 2-\mu 1|$ & DLSD & Increase $(\%)$ \\
\hline $20 \%$ & $87,559.03$ & $69,184.86$ & $18,374.17$ & $20,473.44$ & 20.98 \\
$33 \%$ & $105,169.66$ & $69,184.86$ & $35,984.79^{*}$ & $20,473.44$ & 34.22 \\
$43 \%$ & $129,539.56$ & $69,184.86$ & $60,354.70^{*}$ & $20,473.44$ & 46.59 \\
\hline $0^{\prime}$ & $93,234.54$ & $69,184.86$ & $24,049.68{ }^{*}$ & $20,473.44$ & 25.79 \\
$3^{\prime}$ & $106,155.98$ & $69,184.86$ & $36,971.11^{*}$ & $20,473.44$ & 34.83 \\
$6^{\prime}$ & $122,877.73$ & $69,184.86$ & $53,692.87$ * & $20,473.44$ & 43.70 \\
\hline
\end{tabular}

Table 1 above indicates that, compared to the control values, the MOE values based on the compaction target treatments increased by $20.98 \%$ at $20 \%$ compaction target, $34.22 \%$ at $33 \%$ compaction target, and $46.59 \%$ at $43 \%$ compaction target. Meanwhile, based on the heating time, the MOE values increased by $25.79 \%$ at 0 ' heating time, $34.73 \%$ at 3 ' heating time, and $43.70 \%$ at 6 ' heating time. The increase in the MOE values is logically due to the increased compaction targets so that the wood becomes stiffer and more rigid.

$|\mu 2-\mu 1|$ is the absolute value showing a significant increase and decrease. If $\mu 1>\mu 2>$ DLSD, the increase is significant and if $\mu 1<\mu 2>$ DLSD, the decrease is significant. As shown in the table above, the increased MOE value at the $20 \%$ compaction target was not significant because the difference of $|\mu 2-\mu 1|$ is less than the DLSD value.

The increased MOE values in Table 1 can be depicted in the following histogram.

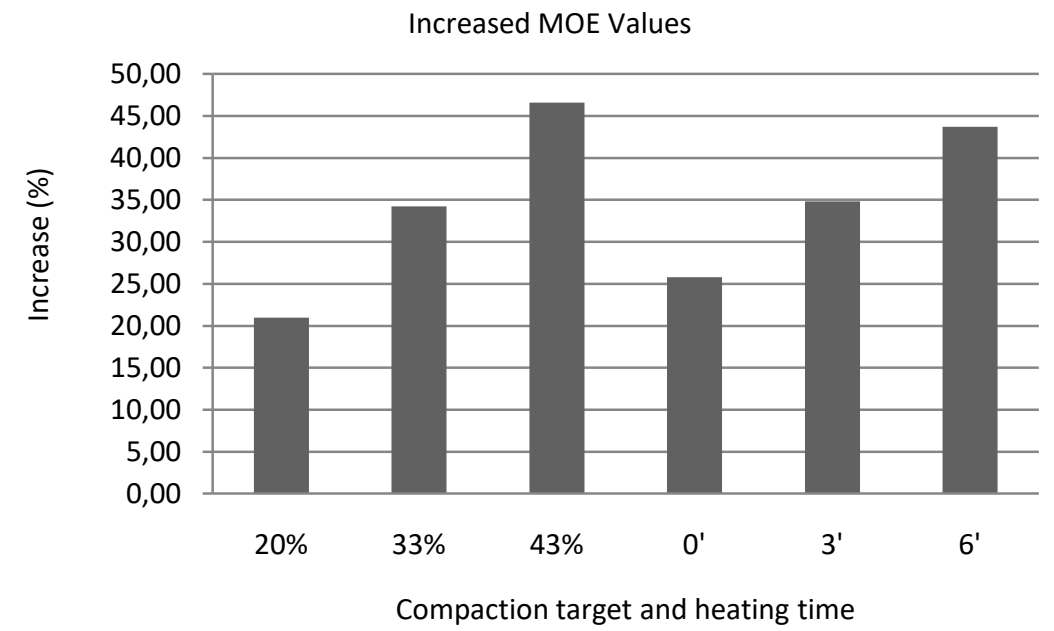

Figure 2 - Increased MOE Values Based on Compaction Target and Heating Time

Table 2 - Increased MOR Values Based on Dunnet's Test Results

\begin{tabular}{llllll}
\hline Target and Waktu & $\mu 1(\mathrm{MOR})$ & $\mu 2($ Control) & $|\mu 2-\mu 1|$ & DLSD & Increase $(\%)$ \\
\hline $20 \%$ & 554.99 & 520.7 & 34.28 & 59.53 & 6.18 \\
$33 \%$ & 582.65 & 520.7 & $61.94{ }^{*}$ & 59.53 & 10.63 \\
$43 \%$ & 656.79 & 520.7 & $136.08{ }^{*}$ & 59.53 & 20.72 \\
\hline $0^{\prime}$ & 540.44 & 520.7 & 19.74 & 59.53 & 3.65 \\
$3^{\prime}$ & 609.4 & 520.7 & $88.69{ }^{*}$ & 59.53 & 14.55 \\
$6^{\prime}$ & 644.58 & 520.7 & $123.88{ }^{*}$ & 59.53 & 19.22 \\
\hline
\end{tabular}

The MOR value variance analysis showed that the densification process was only not influenced by the compaction target treatments. All the criteria analyzed, based on the 
variance of heating time, the interaction of the two (compaction target and heating time), and others, had a significant effect. However, based on Dunnet's advanced test results, the increased MOR values at the $20 \%$ compaction target and the 0 ' heating time did not show a significant difference.

Table 2 confirms that, compared to its control value, the MOR values based on the compaction target treatments increased by $6.18 \%$ at $20 \%$ compaction target, $10.63 \%$ at $33 \%$ compaction target, and $20.72 \%$ at $43 \%$ compaction target. Meanwhile, based on the heating time, the MOR value increased by $3.63 \%$ at 0 ' heating time, $14.55 \%$ at 3 ' heating time, and $19.22 \%$ at 6 ' heating time. The increased MOE values stimulate the increase in the MOR values because the relationship between MOE and MOR is powerful to a certain extent. It is said to a certain extent because it is logically very unlikely for wood to be very stiff and flexible at once. This research further discussed this matter using the MOE/MOR and MOR/MOE ratios.

As explained in the previous, $|\mu 2-\mu 1|$ is the absolute value showing a significant increase and decrease. If $\mu 1>\mu 2>$ DLSD, the increase is significant and if $\mu 1<\mu 2>$ DLSD, the decrease is significant. The table above reveals that the $20 \%$ compaction target and the 0 ' heating time showed an insignificant increase.

The increased MOR values in Table 2 can be depicted in the following histogram.

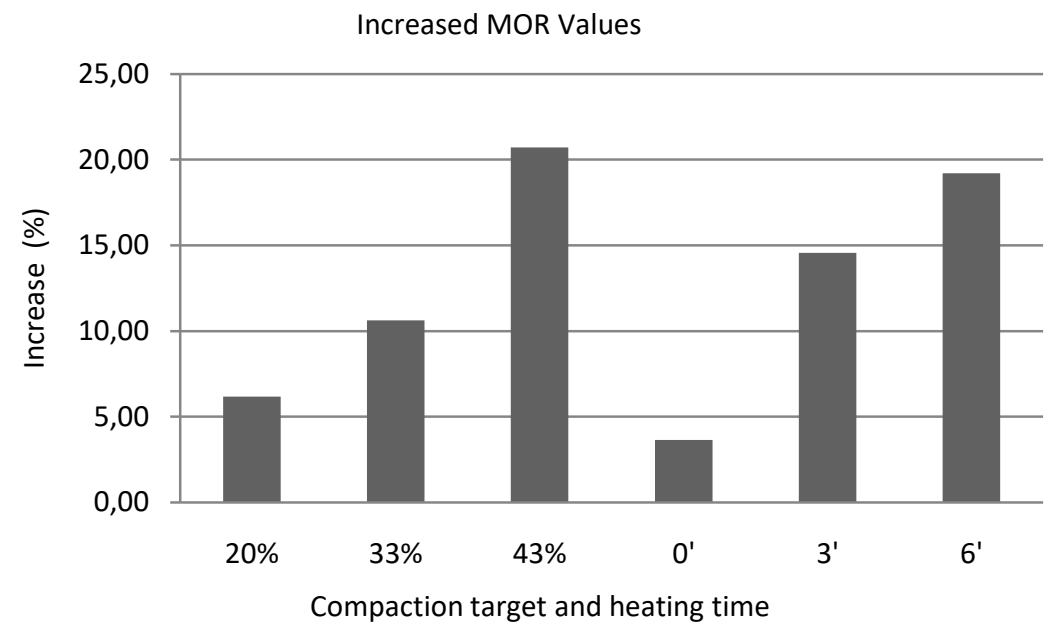

Figure 3 - Increased MOR Values Based on Compaction Target and Heating Time

Each type of wood or object has an ideal equilibrium ratio of MOE/MOR due to its flexibility and stiffness in a particular composition differentiating one another. This perfect equilibrium will change in densified wood, where the results of densification can cause the wood to be more flexible or stiffer. This value cannot be the same because any object, including wood, is very unlikely to be very flexible and stiff at once. The MOE-MOR equilibrium can be illustrated as follows:

$\mathrm{E}$

MOE

MOR

Equilibrium Point

Figure 4 - Illustration of MOE-MOR Equilibrium

The illustration above shows that the equilibrium point $(E)$ changes according to the increase occurring. If the MOE value increases after the densification, the $E$ point will move to the right, while if the MOR value increases after the densification, the $E$ point will move to the left.

The MOE and MOR values can be ratioed for several reasons as follows:

- The calculation of MOE and MOR uses the same unit $\left(\mathrm{kg} / \mathrm{cm}^{2}\right)$; 
- Data are taken using the same sample;

- The calculation of MOE and MOR uses the same data.

Changes in the MOE values due to densification can be seen from the MOE/MOR ratios presented in Table 3 below.

Table 3 - MOE/MOR Ratios as a Benchmark of Changes in MOE Values

\begin{tabular}{lllll}
\hline Target and Time & MOE & MOR & MOE/MOR & MOE $\uparrow / \downarrow$ \\
\hline Control & $69,184.86$ & 520.7 & 132.9 MOR & Control \\
\hline $20 \%$ & $87,559.03$ & 554.99 & 157.8 MOR & $\uparrow$ \\
\hline $33 \%$ & $105,169.66$ & 582.65 & 180.5 MOR & $\uparrow$ \\
\hline $43 \%$ & $129,539.56$ & 656.79 & 197.2 MOR & $\uparrow$ \\
\hline $0^{\prime}$ & $93,234.54$ & 540.44 & 172.5 MOR & $\uparrow$ \\
\hline $6^{\prime}$ & $106,155.98$ & 609.4 & 174.2 MOR & $\uparrow$ \\
\hline
\end{tabular}

Table 3 depicts that MOE values of the densified boards increased compared to those of the control boards. The MOE values increased from $132.9 \mathrm{MOR}$ at the control to 157.8 MOR at $20 \%$ target, $180.5 \mathrm{MOR}$ at $33 \%$ target, and $197.2 \mathrm{MOR}$ at $43 \%$ target based on the target compression. Similarly, based on the heating time, the MOE values increased from 132.9 MOR at the control to 172.5 MOR at 0' time, 174.2 MOR at 3' time, and 190.6 MOR at 6' time.

Here is the MOE/MOR histogram of the densification results.

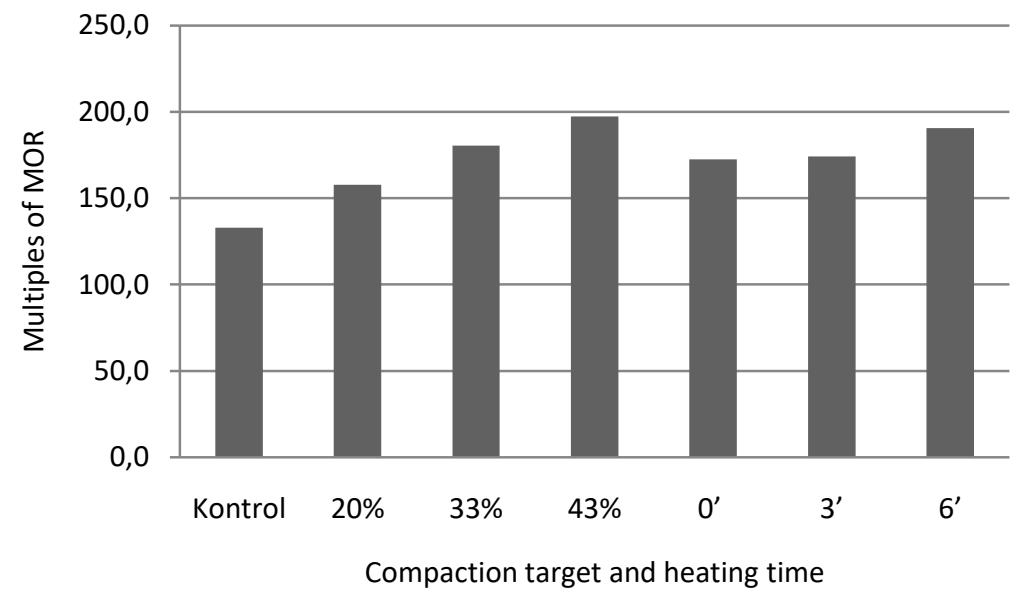

Figure 5 - Multiplies of MOE/MOR Values Based on Compaction Target and Heating Time

Changes in the MOR values after densification can be seen from the MOR/MOE ratios presented in Table 4 below.

Table 4 - MOR/MOE Ratios as a Benchmark of Changes in MOR Values

\begin{tabular}{lllll}
\hline Target and Time & MOE & MOR & MOR/MOE & MOR $\uparrow / \downarrow$ \\
\hline Control & $69,184.86$ & 520.7 & 0.0075 MOE & Control \\
\hline $20 \%$ & $87,559.03$ & 554.99 & 0.0063 MOE & $\downarrow$ \\
\hline $33 \%$ & $105,169.66$ & 582.65 & 0.0055 MOE & $\downarrow$ \\
\hline $43 \%$ & $129,539.56$ & 656.79 & 0.0051 MOE & $\downarrow$ \\
\hline $0^{\prime}$ & $93,234.54$ & 540.44 & 0.0058 MOE & $\downarrow$ \\
\hline $6^{\prime}$ & $106,155.98$ & 609.4 & 0.0057 MOE & $\downarrow$ \\
\hline
\end{tabular}

Table 4 shows that MOR values of the densified boards decreased compared to those of the control boards. The MOR values decreased from $0.0075 \mathrm{MOE}$ at the control to 0.0063 MOE at $20 \%$ target, $0.0055 \mathrm{MOE}$ at $33 \%$ target and $0.0051 \mathrm{MOE}$ at $43 \%$ target based on the 
target compression. Likewise, based on the heating time, the MOR values of the densified board decreased from 0.0075 MOE at the control to 0.0058 MOE at 0' time, 0.0057 MOE at 3' time, and $0.0052 \mathrm{MOE}$ at 6' time.

Here is the MOR/MOE histogram of the densification results.

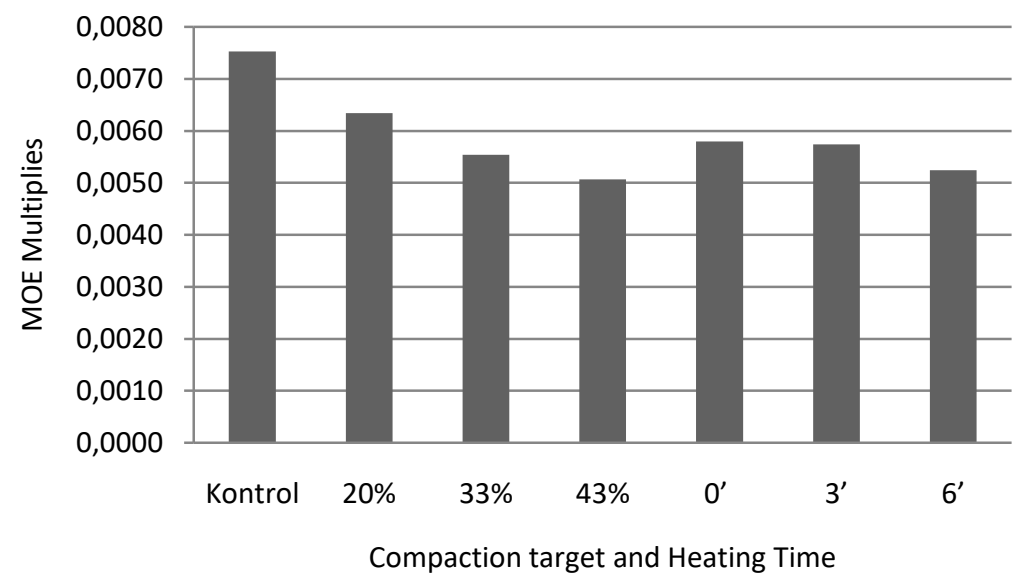

Figure 6 - Multiplies of MOR/MOE Values Based on Compaction Target and Heating Time

\section{CONCLUSION}

Based on Dunnet's advanced test results, the simultaneous increase in the MOE and MOR values compared to the control is relative because, if viewed from the MOE/MOR and MOR/MOE ratios, there could be a decrease in either the MOE or MOR.

The increased MOE value with the MOR unit and the increased MOR value with the MOE unit are easy to understand, as shown in Table 3 and Table 4.

This research indicates that the increased MOE values with the MOR unit presented in Table 3 can decrease the MOR values with the MOE unit, as shown in Table 4.

The ratio method, both $\mathrm{MOE} / \mathrm{MOR}$ and $\mathrm{MOR} / \mathrm{MOE}$, can immediately reveal the increase and decrease in the MOE and MOR values.

The increase or decrease obtained is not relative but absolute because if the MOE value increases, the MOR will decrease and vice versa.

This calculation method can explain that no objects, including wood, are logically able to be increased in stiffness and flexibility at the same time.

\section{REFERENCES}

1. Amin $Y$ and Dwianto W. 2006. Pengaruh suhu and tekanan uap air terhadap fiksasi kayu kompresi dengan menggunakan Close system compression. Jurnal IImu and Teknologi Kayu Tropis 4 (2): 19 - 24. British Standar. 1957. Methods of testing Small Clear Specimens of Timber. Serial BS 373. British standat Institutition. London.

2. Anne Hadiyane. 2011. Perubahan Sifat-Sifat Komponen Penyusun Kayu, Struktur Sel Kayu and Sifat-Sifat Dasar Kayu Terdensifikasi Secara Parsial. Pascasarjana-IPB. Bogor.

3. Arinana and Farah Diba. 2009. Kualitas Kayu Pulai (Alstonia scholaris) Terdensifikasi (Sifat Fisis, Mekanis and Keawetan). Fakultas Kehutanan-IPB. Bogor.

4. Darwis, A. 2008. Fiksasi Kayu Agathis and Gmelina Terpadatkan Pada Arah Radial Serta Observasi Struktur Anatominya. Thesis. Institut Pertanian Bogor. Bogor.

5. Dwianto $W$, Inoue $M$, and Norimoto M. 1997. Fixation of compressive deformation of wood by heat treatment. Mokuzai Gakkaishi. Vol. 43. No. 4. Japan.

6. Dwianto, W.; Morooka, T.; Norimoto, M. 1998c. A Method of Measuring Viscoelastic Properties of Wood under High - Temperature and High - Pressure Steam Conditions. Mokuzai Gakkaishi 44 (2): 77 - 81. 
7. Dwianto W, Mooroka T, Norimoto M. 1999. A Method of measuring viscoelastic properties of wood under high-temperature and high-pressure steam conditions. Jour. Wood Sci 45: 373 - 377. Japan.

8. Dodi Nandika, Wayan Darmawan, and Arinana. 2015. Peningkatan Kualitas Kayu Sengon (Paraserianthes Falcataria (L) NIELSEN) Melalui Teknik Kompregnasi.

9. Farah, D. I. B. A. (2009). Kualitas Kayu Pulai (Alstonia scholaris) Terdensifikasi (Sifat Fisis, Mekanis and Keawetan). Jurnal IImu and Teknologi Hasil Hutan, 2(2).

10. Fengky S. Yoresta, 2015. Pengujian Sifat Mekanik Kayu Merbau Dari Daerah Bogor Jawa Barat. Jurnal Rekayasa Sipil, Jurusan teknik Sipil, Fakultas Teknik, Universitas Andalas.

11. Gerson Eliezer Sailana, Fadillah H. Usman and Ahmad Yani. 2014. Sifat Fisik and Mekanik Kayu Mahang (Macaranga hypoleuca (Reichb.f.et Zoll.) M.A) Yang Dipadatkan Berdasarkan Lama Pengukusan and Besarnya Suhu Kempa. Fakultas KehutananUniversitas Tanjung Pura. Pontianak.

12. Hadjib Nurwati \& Abdurachman, 1999. Sifat Fisis and Mekanis Beberapa Jenis Kayu dari Jawa Barat. Buletin Penelitian Hasil Hutan. Vol. 16 No. 5 (1999) pp. 287 - 292.

13. Hadjib Nurwati dkk. 2007. Sifat Fisis and Mekanis Sepuluh Provenans Kayu Mangium (Acacia mangium Willd.) dari Parung Panjang, Jawa Barat. Jurnal IImu and Teknologi Kayu Tropis.

14. Hartono R, dkk, Sifat Fisis and Mekanis Kayu Karet (Hevea brasiliensis MUELL Arg) Bekas Sadapan and Kayu Karet tanpa Sadapan. Program Studi Kehutanan, Fakultas Kehutanan, Universitas Sumatera.

15. Hastanto B.W, 2011. Kajian Diameter - Persentase Kayu Teras Terhadap Kualitas Kayu Jati (Tectona Grandis Linn. F) Dari Hutan Rakyat Gunung Kidul, Fakultas Kehutanan Institut Pertanian Stiper Yogyakarta. Jurnal Warna Tropika Vol. 1.

16. Haygreen, J.G. and J.L. Bowyer 1996. Hasil Hutan and IImu Kayu. Suatu Pengantar. UGM Press. Bulaksumur. Jogyakarta. (Terjemahan).

17. Kurniawan. 2009. Sifat Fisik Kayu Pulai Yang Terpadatkan Berdasarkan Suhu and Waktu Kempa. Skripsi Fakultas Kehutanan, Universitas Tanjungpura. Pontianak

18. Kollmann, F. J. P., E. E. Kuezi, and A. J. Stamm. 1975. Principle of Wood Science and Technology. Volume II. Wood-Based Material. Springer-Verlag-Berlin-Heidelberg. New York.

19. Mahdie M.F, 2010. Sifat Fisika and Mekanika Kayu Bongin (Irvingia malayana Oliv) Dari Desa Karali lii Kabupaten Murung Raya Kalimantan Tengah Program Studi Teknologi Hasil Hutan, Fakultas Kehutanan Universitas Lambung Mangkurat Jl. A.Yani Km 36 Banjarbaru, Jurnal Hutan Tropis Volume 11 No. 30, Edisi September 2010

20. Martawijaya A, Kartasujana I, Mandang YI, Among S, Kadir and Prawira. 1989. Atlas Kayu Indonesia. Jilid II. Badan Penelitian and Pengembangan Kehutanan. Bogor 438

21. Rakhmat Hidayat. 2012. Perbaikan Kualitas Sifat Mekanis Jenis Kayu Cepat Tumbuh Jabon [Anthocephalus cadamba (Roxb.) Miq.] Dengan Metode Pemadatan. Fakultas Kehutanan-IPB. Bogor.

22. Sulistyono Nugroho, Naresworo Surjokusumo, Surjono. 2003. Teknik Rekayasa Pemadatan Kayu II: Sifat Fisik and Mekanik Kayu Agatis (Agathis lorantifolia Salisb.) Terpadatkan dalam Konstruksi Bangunan Kayu. Fakultas Kehutanan-IPB. Bogor.

23. Tomme FPh, Gigardet F, Gfeller B and Nafi P. 1998. Densified wood: An innovative product with highly enhanced character. Proceeding 5th wood conference on timber engineering vol. 2. Montreux.

24. Tsoumis G. 1991. Science and technology of wood; structure, properties, utilization. Van Nostrand Reinhold. New York.

25. Usman, F. 2002. Sifat Fisis and Mekanis Kayu Sengon yang Diaplikasi Senyawa Khitosan dari Cangkang Udang Windu [Tesis]. Program Pascasarjana. IPB Bogor. Tidak Dipublikasikan.

26. Wardhani IY, 2005. Kajian Sifat Dasar and Pemadatan Bagian Dalam Kayu Kelapa (Cocos nucifera L). Desertasi Sekolah Pascasarjana Institut Pertanian Bogor. Bogor. 